\title{
Induction of DNA damage in the peripheral blood of zebrafish (Danio rerio) by an agricultural organophosphate pesticide, monocrotophos
}

\author{
Avelyno H. D'Costa $\cdot$ S. K. Shyama $\cdot$ M. K. Praveen Kumar • Trisha M. Fernandes
}

Received: 17 April 2018/Accepted: 6 August 2018/Published online: 12 August 2018

(C) The Author(s) 2018

\begin{abstract}
The use of organophosphate pesticides (OPs) in agricultural practices in India has gained popularity due to their broad spectrum, low cost and high potency. Monocrotophos (an OP) which is a systemic and contact broad-spectrum cholinesterase inhibitor is being widely used in India. However, its use entails the damage to other non-target organisms such as fish. In the present study, zebrafish (Danio rerio) were exposed to various doses of monocrotophos $(0.125,0.625$ and $1.25 \mu \mathrm{L} / \mathrm{L})$ and genotoxicity studies were carried out employing the comet assay and micronucleus test in the peripheral blood of these fish after 24, 48 and $72 \mathrm{~h}$ of exposure. Significant DNA damage in the form of $\%$ tail DNA and micronuclei was observed in all the treated fish compared to the control. Both \% tail DNA and micronuclei frequency were found to increase significantly as the concentration increased. DNA damage was also observed at all the time intervals for all treatments except in the $0.125 \mu \mathrm{L} / \mathrm{L}$-treated group. A positive correlation was also observed between the comet assay and micronucleus test. The study thus suggests the use of zebrafish as an experimental model to study the genotoxic effects of agricultural pesticides using the comet assay and micronucleus test.
\end{abstract}

Keywords Comet assay $\cdot$ Micronucleus test $\cdot$ Genotoxicity

\section{Introduction}

Organophosphate pesticides (OPs) are used extensively in agricultural practices around the world due to their high potency and rapid mode of action on a broad spectrum of pests. They are preferred over organochlorines due to their rapid degradation and less environmental persistence. Monocrotophos (MCP), an OP, is used in many parts of the world, particularly in developing countries because of its low cost and is a broad-spectrum pesticide. It is a systemic and contact poison that inhibits cholinesterase and acts as a neurotoxin. Its use, however, entails several undesirable effects particularly in non-target organisms. It is an organic pollutant which is soluble in water and can, therefore, be easily taken up by aquatic fauna. It is labeled as a marine pollutant (FAO/UNEP 1997) and is included under category 1 (highly toxic) by USEPA (1985). It can easily enter the body through oral, dermal or inhalation routes. It is highly toxic to insects, birds and mammals and is moderately toxic to fishes. MCP, as with other pesticides finds its way to the aquatic environment by

A. H. D’Costa · S. K. Shyama $(\bowtie) \cdot$ M. K. Praveen Kumar · T. M. Fernandes

Genetic Toxicology Laboratory, Department of Zoology, Goa University, Goa 403206, India

e-mail: skshyama@gmail.com

A. H. D'Costa

e-mail: avelynodc@gmail.com 
wastewater discharge and monsoon run-offs from agricultural land and thereafter inevitably enters the aquatic food chain.

A number of studies are available on the inhibitory effect of MCP on acetycholine esterase (AChE) activity in different fish species (de Croux et al. 2002; Rao 2004; Kavitha and Rao 2007).

The uptake of xenobiotics also has the capability to induce damage at the level of DNA. They may either affect the DNA directly by causing DNA strand breaks or indirectly by producing reactive oxygen species (ROS) which then damages the DNA by forming adducts or causing lesions (O'Brien 1988; Bagchi et al. 1995; Marnett 2000). DNA repair systems which try to heal the damaged DNA can do so only up to a certain threshold, beyond which DNA damage can persist, in the form of lesions or misrepaired DNA, leading to mutagenesis and carcinogenesis (Moustacchi 2000). Two reliable genotoxicity endpoints which are used for screening the genotoxicity of such xenobiotics are the micronucleus (MN) test and the single-cell gel electrophoresis (comet assay) (Anbumani and Mohankumar 2012; Praveen Kumar et al. 2014, 2015). The MN test is basically used to check the clastogenicity of a particular compound, whereas the comet assay is used to check the effect of the compound on the integrity of DNA (Hartmann et al. 2001; Bolognesi and Cirillo 2014). A number of studies are available on the genotoxicity of other organophosphate pesticides using these tests. Ali and Kumar (2008) studied the genotoxic effects in Channa punctatus exposed to acute treatments of chlorpyrifos and observed DNA damage in the form of micronuclei and percentage tail DNA from the peripheral blood. Similarly, Kumar et al. (2010) also observed the induction of micronuclei and tail DNA in different tissues of $C$. punctatus exposed to malathion. The genotoxicity of MCP has been reported in estuarine bivalves (Revankar and Shyama 2009). However, few studies are available on the genotoxicity of this pesticide in teleost fishes. Tilapia mossambica treated with different concentrations of MCP were reported to have significant DNA damage in their erythrocytes as observed by the comet assay (Banu et al. 2001). In another study, Ali and Kumar (2008) reported the DNA damage induced by MCP in the gills, kidneys and lymphocytes of $C$. punctatus using the comet assay. Besides fish, the genotoxicity of MCP has been reported in mice (Mahboob et al. 2002), in rats (Yaduvanshi et al. 2010) and in human peripheral blood lymphocytes (Das et al. 2007).

Although a number of fish models are used for toxicity screening of aquatic environment, the teleost cyprinid, zebrafish (Danio rerio) is the most popular choice because of its prominence as a toxicological model (Hill et al. 2005; Sipes et al. 2011). A few studies have been carried out on the different effects of MCP on zebrafish such as the estrogenic and feminizing effects of MCP (Zhang et al. 2013) and cortisol-mediated stress responses (Zhang et al. 2015). In a recent study, different concentrations of MCP were used to evaluate the developmental response of zebrafish embryos (Pamanji et al. 2015). Mortality was observed in all the test concentrations along with a large number of morphological abnormalities. However, there is no information on the DNA damaging effects of MCP in adult zebrafish, and therefore, the present study was carried out to assess the genotoxicity of different concentrations of this OP.

\section{Materials and methods}

Quality assurance and quality control

The appropriate quality assurance methods of sample preparation, handling and preservation were carried out in accordance with US EPA procedures. All chemicals used were of analytical grade from Himedia (Himedia, India).

Experimental fish

Zebrafish were handled and maintained as per the European Union directive on the protection of animals used for scientific purposes (EU 2010). Male zebrafish (D. rerio) (12-month old and size $4.0 \pm 0.3 \mathrm{~cm}$ ) were procured from a fish rearing and breeding farm from Pune, India and were transported in well-oxygenated polythene bags to the laboratory. They were maintained in filtered tap water in aquaria $(25 \mathrm{~L})$ with aerators 
and temperature regulators at $28^{\circ} \mathrm{C}, 12 \mathrm{~h}$ light/dark cycle, $\mathrm{pH} 7.0 \pm 0.15$ and DO $8.5 \pm 1.0$. They were fed with commercial feed pellets. Foam filters were used to collect the accumulated fecal matter and were cleaned every alternate day. Water was changed once a week. Thus, these fish were acclimatized in the laboratory conditions for 30 days.

\section{Monocrotophos}

Monocrotophos $\left[\mathrm{C}_{7} \mathrm{H}_{14} \mathrm{NO}_{5} \mathrm{P}\right.$, dimethyl (E)-1-methyl-2-(methylcarbamoyl) vinyl phosphate, MCP], of commercial grade (37\% water soluble) was procured from Sds Ramcides Cropscience Pvt Ltd, Chennai, India (Batch No. R/P/879).

Treatment schedule

The fish were distributed into groups; each containing ten fishes in the same aquaria mentioned above and was used for dose-response studies as well as time-response studies. Based on the LC50 value of MCP on Tilapia mossambicus as per Mustafa et al. (1982), three sub-lethal doses, i.e., 0.125, 0.625, $1.25 \mu \mathrm{L} / \mathrm{L}$ were selected and exposed in triplicates. Acute toxicity studies were also carried out at 24, 48 and $72 \mathrm{~h}$ of exposure without renewal of MCP.

Validation of the comet assay and micronucleus test

A separate group of fish (ten individuals) treated with cyclophosphamide (1, 3 and $5 \mathrm{mg} / \mathrm{L}$ in water), a wellknown genotoxin was used as a positive control at different time intervals $(24,48$ and $72 \mathrm{~h})$ and the comet assay and micronucleus test were validated.

Cell viability

Prior to the comet assay and micronucleus test, the cell count and cell viability of the peripheral blood were checked to ensure that there were enough living cells to perform the assay employing trypan blue dye exclusion test. The samples showing more than $90 \%$ viability and a cell count of a minimum of $10^{6}$ cells $/ \mathrm{mL}$ were used for the tests.

Comet assay (alkaline single-cell gel electrophoresis)

The comet assay was performed according to the protocol of Ferraro et al. (2004) with slight modifications. All the steps were carried out in $\operatorname{dim}$ light and at $4{ }^{\circ} \mathrm{C}$ to prevent photo-oxidation of DNA. Peripheral blood was collected from the fish by caudal puncture and suspended in phosphate buffered saline $(\mathrm{Ca}+\mathrm{Mg}+\mathrm{free}$, $\mathrm{pH}$ 7.2). $20 \mu \mathrm{L}$ of this blood suspension was mixed with low-melting agarose (LMA) and overlaid on a base layer of normal-melting agarose on frosted microscopic slides. These slides were placed in a cold lysing solution (2.5 M NaCl, $100 \mathrm{mM} \mathrm{Na}_{2}$ EDTA, $10 \mathrm{Mm}$ Tris, $10 \%$ DMSO And 1\% Triton-X pH 10, $4{ }^{\circ} \mathrm{C}$ ) for $1 \mathrm{~h}$. The slides were then transferred to an electrophoretic unit containing unwinding buffer $(\mathrm{pH}>10)$ for 20 min to allow the DNA to unwind. Electrophoresis was then performed under alkaline conditions ( $\mathrm{pH} 10)$ for 20 min at $300 \mathrm{~mA}, 25 \mathrm{~V}$. After electrophoresis, the slides were placed in neutralization buffer (400 mM Tris base, $\mathrm{pH} 7.5$ ) for $5 \mathrm{~min}$. About $25 \mu \mathrm{L}$ of ethidium bromide stain was applied in four-to-five small, equally sized droplets over the gel, covered with a coverslip and examined using a fluorescence microscope (Olympus BX53) with a green filter at $200 \times$ magnification. Two slides per fish were prepared and 100 "comets" were screened per slide. Images of the comets of non-overlapping cells were captured using an attached camera and analyzed with the help of computer software, CASP (Konca et al. 2003). The \% tail DNA was recorded which is used as a reliable measure of DNA damage (Kumaravel and Jha 2006; Praveen Kumar et al. 2014). 
Micronucleus test

The MN test was performed as per Baršiene et al. (2006). Briefly, a small drop of the blood collected by caudal puncture was immediately smeared on clean glass slides, allowed to air-dry, fixed in absolute methanol for $10 \mathrm{~min}$ and stained with $5 \%$ Giemsa for $30 \mathrm{~min}$. Three slides per fish were prepared. The frequency of micronuclei $(\mathrm{MNi})$ in erythrocytes was evaluated by scoring 5000 intact cells per fish at $1000 \times$ magnification. MNi were identified as structures with the following morphological features: (1) spherical or ovoid-shaped extra-nuclear bodies in the cytoplasm (2) a diameter of 1/3-1/20 of the main nucleus (3) non-refractory bodies (4) color texture resembling that of the nucleus, and (5) the bodies completely separated from the main nucleus (Fenech et al. 2003).

\section{Statistical analysis}

Statistical analyses of the data were carried out using IBM SPSS 23 statistical software package. Since the data are expressed as percentage values, arc sine transformation of the variables were computed and were tested to check the normality and homogeneity of variance using Shapiro-Wilk test and Welch's test, respectively, before being analyzed. A two-way ANOVA was applied to test the effect of dose as well as time on the DNA damage parameters and also the interactions between them followed by a post hoc Dunnet's test to compare the different groups with the control within the same treatment group or time interval group. Pearson's correlation with a scatter plot was also used to test the relationship between the frequency of $\mathrm{MNi}$ and $\%$ tail DNA. The data were considered to be statistically significant at $p<0.05$.

\section{Results}

The DNA damage (\% tail DNA) induced by different concentrations of CP (1, 3, and $5 \mathrm{mg} / \mathrm{L})$ in the blood cells of zebrafish at various time intervals $(24,48$ and $72 \mathrm{~h})$ is shown in Fig. 1a ,b. All the doses of CP induced a significant increase in $\%$ tail DNA and \% MNi compared to the control (Figs. 1, 2).

A significant increase of dose-dependent damage $(p<0.05)$ was observed in the form of $\%$ tail DNA in the erythrocytes of D. rerio compared to the control (Fig. 3). Tail DNA (\%) was also found to increase significantly with advancing time.

A significant increase in the frequency of micronuclei (MNi) was also observed in the erythrocytes for the 0.62 and $1.25 \mu \mathrm{L} / \mathrm{L}$ treatment groups (Fig. 4). However, in the time-dependent studies, there was no significant increase of $\mathrm{MNi}$ formation after 24 and $48 \mathrm{~h}$ in the $0.125 \mu \mathrm{L} / \mathrm{L}$ treatment group although there was a significant increase after $72 \mathrm{~h}$.

The results of the two-way ANOVA (Table 1) indicate the effect of treatments and time as well as their interactions (treatment $\times$ time) on the $\%$ tail DNA and $\mathrm{MNi}$. The treatment variable contributed the most to the $\%$ tail DNA $(F=1739.89, p<0.001)$ and to a lesser extent, $\mathrm{MNi}(F=697.98, p<0.001)$. On the other

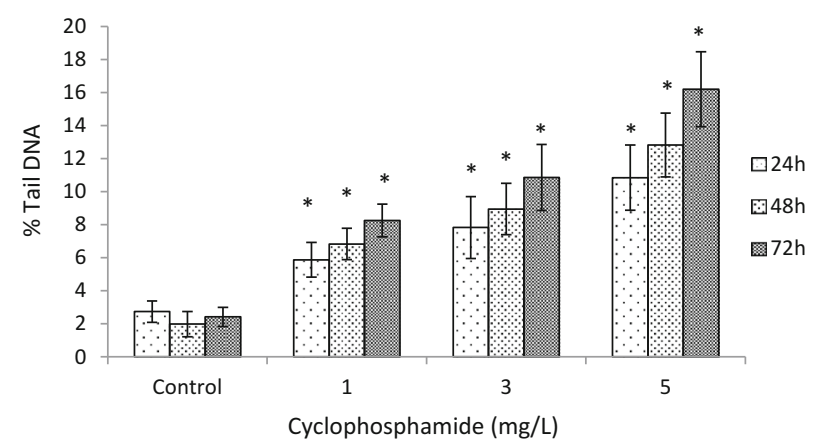

Fig. 1 Tail DNA (\%) in erythrocytes of D. rerio exposed to different treatments of cyclophosphamide at different intervals of time. Statistical differences $(* p<0.05)$ are in relation to the control of the respective time interval 


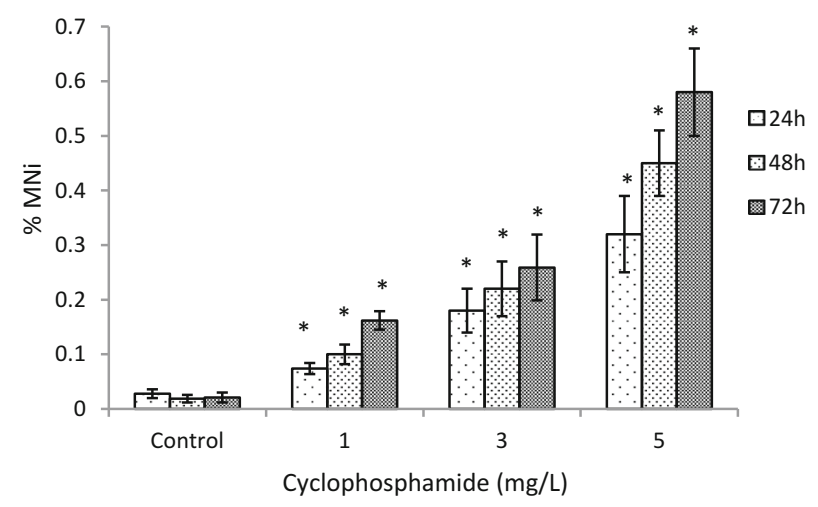

Fig. $2 \mathrm{MNi}(\%)$ in erythrocytes of D. rerio exposed to different treatments of cyclophosphamide at different intervals of time. Statistical differences $(* p<0.05)$ are in relation to the control of the respective time interval

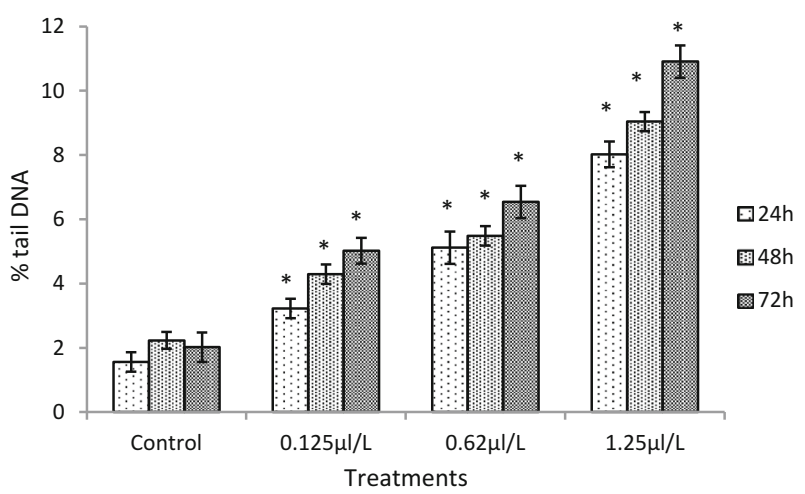

Fig. 3 Tail DNA (\%) in erythrocytes of D. rerio exposed to different treatments of monocrotophos at different intervals of time. Statistical differences $\left({ }^{*} p<0.05\right)$ are in relation to the control of the respective time interval

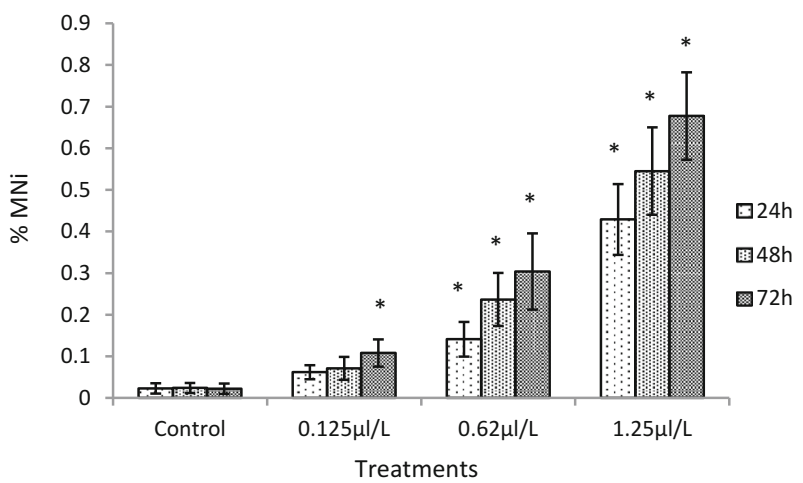

Fig. $4 \mathrm{MNi}(\%)$ in erythrocytes of D. rerio exposed to different treatments of monocrotophos at different intervals of time. Statistical differences $(* p<0.05)$ are in relation to the control of the respective time interval

hand, the time variable had the most effect on MNi $(F=25.8, p<0.001)$ followed by the $\%$ tail DNA $(F=10.96, p<0.001)$. The interaction of the two independent variables (treatment $\times$ time), however, influenced only the formation of $\mathrm{MNi}(F=4.56, p<0.01)$.

The data of the arc sine-transformed $\%$ tail DNA and \% MNi were found to be highly correlated by Pearson's correlation analysis $(R=0.92)$ and the relationship is plotted in the form of a scatter plot in Fig. 5 . A significant positive correlation is, therefore, found to exist between these two parameters of DNA damage $\left(R^{2}=0.86\right)$. 
Table 1 Two way ANOVA testing the influence of treatments and time as well as the interaction between them (treatment $\times$ time) on the DNA damage parameters in erythrocytes of $D$. rerio exposed to monocrotophos

\begin{tabular}{|c|c|c|c|c|c|c|}
\hline \multirow[t]{4}{*}{ Dependent variable } & \multicolumn{6}{|c|}{ Independent variables } \\
\hline & \multicolumn{4}{|l|}{ Factors } & \multirow{2}{*}{\multicolumn{2}{|c|}{$\frac{\text { Interaction }}{\text { Treatment } \times \text { time }}$}} \\
\hline & \multicolumn{2}{|c|}{ Treatment } & \multicolumn{2}{|l|}{ Time } & & \\
\hline & $F$ value & $p$ & $F$ value & $p$ & $F$ value & $p$ \\
\hline$\%$ tail DNA & 1739.89 & $<0.001$ & 10.96 & $<0.001$ & 1.36 & ns \\
\hline $\mathrm{MNi}$ & 697.98 & $<0.001$ & 25.80 & $<0.001$ & 4.56 & $<0.01$ \\
\hline
\end{tabular}

ns non-significant

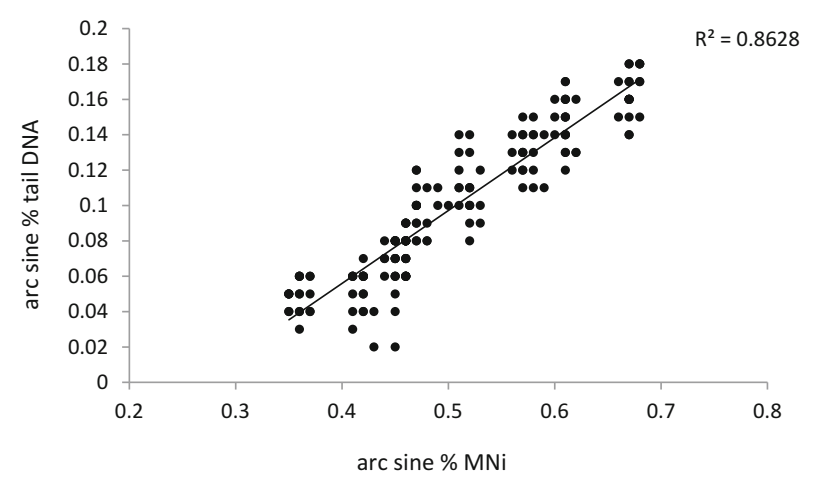

Fig. 5 Scatter plot showing the relationship between arc sine-transformed data of \% tail DNA and MNi

\section{Discussion}

The present study revealed the genotoxicity of MCP in the peripheral blood cells of zebrafish as indicated by the comet assay and the micronucleus test. Further, genetic damage increased with increasing doses and time intervals. Our results are in agreement with that of Anbumani and Mohankumar (2015) in which they observed that freshwater fish (Catla catla) exposed to various doses of MCP exhibited a dose and time-dependent increase of DNA damage in the form of micronuclei. Our results also find similarity with the studies of Ali and Kumar (2008) wherein significantly high \% tail DNA was induced in the erythrocytes of $C$. punctatus exposed to MCP. They reported that the DNA damage was highest on the fourth day, i.e., $96 \mathrm{~h}$ after exposure and the same was also evident in the present study in which DNA damage was highest on the third day, i.e., $72 \mathrm{~h}$ after exposure for all the doses. However, Banu et al. (2001) observed maximum DNA damage in the erythrocytes of Tilapia mossambica exposed to different doses of MCP at $24 \mathrm{~h}$ after exposure and a subsequent decrease of DNA damage at later time intervals. These differences in DNA recovery may be attributed to the rate of metabolite removal/detoxification or DNA repair capacity of different species. In the time-dependent study, MCP did not induce significant DNA damage at $0.125 \mu \mathrm{L} / \mathrm{L}$ at 24 and $48 \mathrm{~h}$ of exposure. This may probably be due to the initial low concentration of the toxicant which could not induce any immediate noticeable effects but did affect DNA at the $72 \mathrm{~h}$ time interval. This subsequent increase in DNA damage may have occurred due to gradual bioaccumulation of MCP over the span of $72 \mathrm{~h}$. Further, the results of the two-way ANOVA suggest that both time and treatment play an important role in the formation of DNA strand breaks and micronuclei.

Our results also find similarities with studies on other related organophosphate pesticides by several workers. Ali et al. (2009) reported the induction of micronuclei and tail DNA by various treatments of chlorpyrifos, in the erythrocytes and lymphocytes of $C$. punctatus. They also reported that DNA damage was highest on the third day after exposure at all the concentrations of chlorpyriphos. Similar observations were reported by Mohanty et al. (2011) in which the erythrocytes of Labeo rohita fingerlings exposed to another OP, phorate exhibited significant DNA damage which declined after $72 \mathrm{~h}$ of exposure. Sub-lethal doses of 
profenofos, an OP pesticide were found to induce DNA strand breaks in the gill cells of $C$. punctatus and was found to increase in a dose-dependent manner (Pandey et al. 2011). DNA damage was also observed in the gill cells of the European eel (Anguilla anguilla) exposed to the OP glyphosate (Guilherme et al. 2012). Ali et al. (2014) also reported the time-dependent and dose-dependent increase of genotoxicity of an OP insecticide, dimethoate in $C$. punctatus, which were found to be highly correlated with oxidative stress. Our results along with those of Pamanji et al. (2015) mentioned earlier, provide information on the toxic effects of MCP in both the adults and embryos of zebrafish suggesting that MCP can affect zebrafish at any time during its life cycle.

Organophosphate pesticides such as MCP and those cited above cause the alkylation of DNA bases either directly or indirectly by protein alkylation leading to DNA disintegration (Bhinder and Chaudhry 2013). The presence of a methyl ester group is more likely to cause alkylation than ethyl esters or other higher esters and thus MCP is more reactive than other organophosphate pesticides (Yaduvanshi et al. 2010). Alternatively, the phosphorous group in OPs may be a favorable substrate for nucleophilic attack which in turn may cause DNA phosphorylation and consequently, DNA damage (Rahman et al. 2002; Das et al. 2007). Another reason for damaged DNA could be oxidative stress due to the formation of reactive oxygen species (ROS). Oxidative stress may be caused due to the production of ROS above the level of detoxification and repair. The free radicals thus formed can affect DNA indirectly by lipid peroxidation which in turn causes single-stranded breaks (SSB) (Yaduvanshi et al. 2010; Nwani et al. 2011). Lipid peroxidation products such as 4-hydroxynonenal and malondialdehyde (MDA) which are the most genotoxic and mutagenic, respectively, form adducts with DNA thereby causing DNA damage (Luczaj and Skrzydlewska 2003). Thus, DNA damage prevailing in the erythrocytes of zebrafish may be due to the combined direct or indirect effects.

We also observed that the induction of tail DNA had a strong positive correlation with induction of micronuclei in zebrafish erythrocytes. The reason for correlating these two genotoxicity tests is that they reflect different forms of environmental stress. MCP, as mentioned earlier can induce SSBs which may be easily repaired and these transient DNA breaks can be easily detected by the comet assay. However, DNA damage which is difficult to repair tends to form extra-nuclear bodies or micronuclei which can be detected by the micronucleus test (Hartmann et al. 2001). These micronuclei are formed when a whole chromosome or a fragment of a chromosome do not get incorporated into either of the two daughter cells during cell division due to aneugenic agents that affect the spindle apparatus or clastogenic agents that damage and break the chromosome (Udroiu 2006). The comet assay and micronucleus test can, therefore, be applied on zebrafish erythrocytes and be used as an integrated part of a monitoring program of water bodies that might be contaminated with organophosphate pesticides.

\section{Conclusions}

The present study thus revealed the ability of MCP to induce DNA damage in zebrafish erythrocytes. The formation of MNi and tail DNA is highly correlated with each other and may occur in a dose-dependent and/or time-dependent manner. The MN test and comet assay can, therefore, be reliably used to assess the genotoxicity of MCP in the aquatic environment using zebrafish as a toxicological model. Despite several reports of induced toxicity mentioned earlier, MCP still continues to be used in agricultural practices and may affect aquatic fauna at the DNA level. Therefore, it is suggested to limit its use in agricultural practices to avoid the potential contamination and of nearby water bodies. Although there is a lack of data concerning the health implications of consuming fish contaminated with organophosphate pesticides, care and caution should be taken due to probable persistence of these residues.

\section{Compliance with ethical standards}

Conflict of interest The authors report no conflicts of interest. The authors alone are responsible for the content and writing of the paper.

Open Access This article is distributed under the terms of the Creative Commons Attribution 4.0 International License (http:// creativecommons.org/licenses/by/4.0/), which permits unrestricted use, distribution, and reproduction in any medium, provided you give appropriate credit to the original author(s) and the source, provide a link to the Creative Commons license, and indicate if changes were made. 


\section{References}

Ali D, Kumar S (2008) Long-term genotoxic effect of monocrotophos in different tissues of freshwater fish Channa punctatus (Bloch) using alkaline single cell gel electrophoresis. Sci Total Environ 405:345-350

Ali D, Nagpure NS, Kumar S, Kumar R, Kushwaha B (2009) Genotoxicity assessment of acute exposure of chlorpyrifos to freshwater fish Channa punctatus (Bloch) using micronucleus assay and alkaline single-cell gel electrophoresis. Chemosphere 71:1823-1831

Ali D, Kumar PG, Kumar S, Ahmed M (2014) Evaluation of genotoxic and oxidative stress response to dimethoate in freshwater fish Channa punctatus (Bloch). Chem Speciat Bioavailab 26:111-118

Anbumani S, Mohankumar MN (2012) Gamma radiation induced micronuclei and erythrocyte cellular abnormalities in the fish Catla catla. Aquat Toxicol 122-123:125-132

Anbumani S, Mohankumar MN (2015) Cytogenotoxicity assessment of monocrotophos and butachlor at single and combined chronic exposures in the fish Catla catla (Hamilton). Environ Sci Pollut Res 7:4964-4976

Bagchi D, Bagchi M, Hassoun EA, Stohs SJ (1995) In vitro and in vivo generation of reactive oxygen species, DNA damage and lactate dehydrogenase leakage by selected pesticides. Toxicology 104:129-140

Banu BS, Danadevi K, Rahman MF, Ahuja YR, Kaiser J (2001) Genotoxic effect of monocrotophos to sentinel species using comet assay. Food Chem Toxicol 39:361-366

Baršiene J, Dedonyte V, Rybakovas A, Andreikenait L, Andersen OK (2006) Investigation of micronuclei and other nuclear abnormalities in peripheral blood and kidney of marine fish treated with crude oil. Aquat Toxicol 78S:S99-S104

Bhinder P, Chaudhry A (2013) Mutagenicity assessment of organophosphates using polymerase chain reaction-restriction fragment length polymorphism assay. Toxicol Int 20:254-260

Bolognesi C, Cirillo S (2014) Genotoxicity biomarkers in aquatic bioindicators. Curr Zool 60:273-284

Das PP, Shaik AP, Jamil K (2007) Genotoxicity induced by pesticide mixtures: in vitro studies on human peripheral blood lymphocytes. Toxicol Ind Health 23:449-458

de Croux MJP, Loteste A, Cazenave J (2002) Inhibition of plasma cholinesterase and acute toxicity of monocrotophos in a neotropical fish Prochilodus lineatus (Pisces, Curimatidae). Bull Environ Contam Toxicol 69:356-363

EU (2010) Directive 2010/63/EU of the European parliament and of the council of 22 September 2010 on the protection of animals used for scientific purposes. Off J EU L 276:33-79

FAO/UNEP (1997) Decision Guidance Documents: Methamidophos - Methyl parathion - Monocrotophos - Parathion Phosphamidon

Fenech M, Chang WP, Kirsch-Volders M, Holland N, Bonassi S, Zeiger E (2003) HUMN project: detailed description of the scoring criteria for the cytokinesis-block micronucleus assay using isolated human lymphocyte cultures. Mutat Res 534:65-75

Ferraro MV, Fenocchio AS, Mantovani MS, Cestari MM, Ribeiro CAO (2004) Mutagenic effects of tributyltin (TBT) and inorganic lead (PbII) on the fish H. malabaricus as evaluated using the comet assay, piscine micronucleus and chromosome aberrations tests. Genet Mol Biol 27:103-107

Guilherme S, Gaivão I, Santos MA, Pacheco M (2012) DNA damage in fish (Anguilla anguilla) exposed to a glyphosate-based herbicide-elucidation of organ-specificity and the role of oxidative stress. Mutat Res 743:1-9

Hartmann A, Elhajouji A, Kiskinis E, Poetter F, Martus HJ, Fjällman A, Frieauff W, Suter W (2001) Use of the alkaline assay for industrial genotoxicity screening: comparative investigation with the micronucleus test. Food Chem Toxicol 39:843-858

Hill AJ, Teraoka H, Heideman W, Peterson RE (2005) Zebrafish as a model vertebrate for investigating chemical toxicity. Toxicol Sci 86:6-19

Kavitha P, Rao JV (2007) Oxidative stress and locomotor behaviour response as biomarkers for assessing recovery status of mosquito fish, Gambusia affinis after lethal effect of an organophosphate pesticide, monocrotophos. Pestic Biochem Physiol $87: 182-188$

Konca K, Lankoff A, Banasik A, Lisowska H, Kuszewski T, Gózdz S, Koza Z, Wojcik A (2003) A cross-platform public domain PC image-analysis program for the comet assay. Mutat Res 534:15-20

Kumar R, Nagpure NS, Kushwaha B, Srivastava SK, Lakra WS (2010) Investigation of the genotoxicity of malathion to freshwater teleost fish Channa punctatus (Bloch) using the micronucleus test and comet assay. Arch Environ Contam Toxicol $58: 123-130$

Kumaravel TS, Jha AN (2006) Reliable comet assay measurements for detecting DNA damage induced by ionising radiation and chemicals. Mutat Res 605:7-16

Łuczaj W, Skrzydlewska E (2003) DNA damage caused by lipid peroxidation products. Cell Mol Biol Lett 8:391-413

Mahboob M, Rahman MF, Danadevi K, Banu BS, Grover P (2002) Detection of DNA damage in mouse peripheral blood leukocytes by the comet assay after oral administration of monocrotophos. Drug Chem Toxicol 25:65-74

Marnett LJ (2000) Oxyradicals and DNA damage. Carcinogenesis 21:361-370

Mohanty G, Mohanty J, Nayak AK, Mohanty S, Dutta SK (2011) Application of comet assay in the study of DNA damage and recovery in rohu (Labeo rohita) fingerlings after an exposure to phorate, an organophosphate pesticide. Ecotoxicology 20:283-292

Moustacchi E (2000) DNA damage and repair: consequences on dose-responses. Mutat Res 464:35-40

Mustafa AM, Anjum F, Qadri SSH (1982) A technique to evaluate acute toxicity of insecticide (technical and formulation) to freshwater fish, Tilapia mossambica. Int Pest Control 24:4

Nwani CD, Nagpure NS, Kumar R, Kushwahab B, Kumar P, Lakra WS (2011) Mutagenic and genotoxic assessment of atrazinebased herbicide to freshwater fish Channa punctatus (Bloch) using micronucleus test and single cell gel electrophoresis. Environ Toxicol Pharmacol 31:314-322 
O'Brien PJ (1988) Radical formation during the peroxidase catalyzed metabolism of carcinogens and xenobiotics: the reactivity of these radicals with GSH, DNA, and unsaturated lipid. Free Radic Biol Med 4:169-183

Pamanji R, Bethu MS, Yashwanth B, Leelavathi S, Rao VJ (2015) Developmental toxic effects of monocrotophos, an organophosphorous pesticide, on zebrafish (Danio rerio) embryos. Environ Sci Pollut Res Int 10:7744-7753

Pandey AK, Nagpure NS, Trivedi SP, Kumar R, Kushwaha B (2011) Profenofos induced DNA damage in freshwater fish, Channa punctatus (Bloch) using alkaline single cell gel electrophoresis. Mutat Res 726:209-214

Praveen Kumar MK, Shyama SK, Sonaye BS, Naik RU, Kadam SB, Bipin PD, D'costa A, Chaubey RC (2014) Evaluation of $\gamma$ radiation induced DNA damage in two species of bivalves and their relative sensitivity using comet assay. Aquat Toxicol 150:1-8

Praveen Kumar MK, Shyama SK, Sonaye BS, D'costa A, Chaubey RC (2015) The effect of gamma radiation on the Common carp (Cyprinus carpio): in vivo genotoxicity assessment with the micronucleus and comet assays. Mutat Res 792:19-25

Rahman MF, Mahboob M, Danadevi K, Banu SB, Grover P (2002) Assessment of genotoxic effects of chloropyriphos and acephate by the comet assay in mice leucocytes. Mutat Res 516:139-147

Rao JV (2004) Effects of monocrotophos and its analogs in acetylcholinesterase activity's inhibition and its pattern of recovery on euryhaline fish, Oreochromis mossambicus. Ecotoxicol Environ Saf 59:217-222

Revankar PR, Shyama SK (2009) Genotoxic effects of monocrotophos, an organophosphorous pesticide, on an estuarine bivalve, Meretrix ovum. Food Chem Toxicol 47:1618-1623

Sipes NS, Padilla S, Knudsen TB (2011) Zebrafish: as an integrative model for twenty-first century toxicity testing. Birth Defects Res C Embryo Today 93:256-267

Udroiu I (2006) The micronucleus test in piscine erythrocytes. Aquat Toxicol 79:201-204

USEPA (1985) Pesticide fact sheet no 72: monocrotophos. USEPA, Washington D.C.

Yaduvanshi SK, Ojha A, Pant SC, Lomash V, Srivastava N (2010) Monocrotophos induced lipid peroxidation and oxidative DNA damage in rat tissues. Pestic Biochem Physiol 97:214-222

Zhang X, Gao L, Yang K, Tian H, Wang W, Ru S (2013) Monocrotophos pesticide modulates the expression of sexual differentiation genes and causes phenotypic feminization in zebrafish (Danio rerio). Comp Biochem Physiol C Toxicol Pharmacol 157:33-40

Zhang X, Zhong Y, Tian H, Wang W, Ru S (2015) Impairment of the cortisol stress response mediated by the hypothalamuspituitary-interrenal (HPI) axis in zebrafish (Danio rerio) exposed to monocrotophos pesticide. Comp Biochem Physiol C Toxicol Pharmacol 176-177:10-16

\section{Publisher's Note}

Springer Nature remains neutral with regard to jurisdictional claims in published maps and institutional affiliations. 